\title{
Dolnozemskí Slováci a ich literárna tvorba
}

\author{
Ĺudmila Ozábalová
}

Patrik Šenkár: Slovenská dolnozemská literatúra (v teórii a praxi). Komárno: Univerzita J. Selyeho v Komárne, Pedagogická fakulta, 2015. 218 s. ISBN 978-808122-133-0.

Slovenská literatúra vzniká aj za geografickými hranicami Slovenskej republiky. Tvoria ju krajania, ktorí z takých či onakých dôvodov odišli, resp. museli odíst' z územia materskej krajiny. Slovenské písané slovo je teda živé tam, kde žijú a tvoria Slováci: v rôznych častiach Európy, Ameriky, Austrálie...

V pozadí uvedených skutočností títo ludia nie sú nečinní, ale na rôznej úrovni, v inakšej híbke i šírke vytvárajú kultúrne hodnoty, ktoré sa plne etablujú do rôznych kontextov. Krajania majú svoju špecifickú identitu a na základe (i v pozadí) nej pulzujú. Zachovávajú si svoje zvyky, obyčaje či tradície, ktoré sa po stáročia „nahromadili“. Uvedomujú si svoje jedinečné postavenie, ktoré je demokratické v pozadí akceptácie okolitých daností a entít. Ondrej Štefanko, významná osobnost' Slovákov v zahraničí, o tom napísal: „Slovákmi, aj ked’ žijúcimi v zahraniči, sme a budeme iba dovtedy, kým si, nikým nenúteni, našu príslušnost' budeme deklarovat' a kým nebudeme chciet'splynút's ostatnými. A myslím si, že $i$ vztah Slovenskej republiky $k$ slovenským zahraničným komunitám a $k$ Slovákom žijúcim v zahranič by mal vychádzat práve z týchto súradnic." V pozadí tejto vzácnej myšlienky je teda potrebné neustále úsilie o (seba)reflexiu v pozadí kultúrnosti a kultivovanosti. Len tak sa vyvíja ludské spoločenstvo, teda aj národnostná skupina.

Celkový odhad počtu Slovákov v zahraničí je okolo 2 miliónov. Kultúrne a spoločensky významná čast’ z nich žije na tzv. Dolnej zemi. Pod ňou rozumieme všetky historicky vzniknuté, Slovákmi osídlené územia, ležiace južne od slovensko-mad'arskej etnickej hranice (vrátane Zadunajska, Novohradu, Bukoviny a Bulharska), resp. časti Uhorska, ktoré boli v 18. a 19. storočí kolonizované Slovákmi. V súčasnosti žijú dolno- zemskí Slováci v Mad’arsku, Rumunsku a Srbsku (vo Vojvodine).

V terajšom Mad’arsku žijú Slováci (v Komárňansko-ostrihomskej, Békešskej, Boršodsko-abovsko-zemplínskej, Novohradskej a Peštianskej župe a v Budapešti) ako tretia najpočetnejšia národnostná menšina. Ich počet sa pohybuje okolo osemnástitisíc podla oficiálneho sčítania ludu. Strediskom ich kultúrneho života je najmä Békešská Čaba. Je to autochtónne obyvatel'stvo, ale žijúce aj v týchto končinách v dôsledku migrácie v rámci bývalého Uhorska po vyhnaní Turkov v 18. a 19. storočí. Od devätdesiatych rokov 20. storočia majú Celoštátnu slovenskú samosprávu a samosprávy na regionálnej úrovni. V krajine sú dve národnostné slovenské gymnáziá: v Budapešti a Békešskej Čabe. Týždenník Ludové noviny má aj internetové vydanie; ich novodobé literárne snaženie sa datuje od roku 1955, rozmach od sedemdesiatych rokov 20. storočia.

Dnes žije v Rumunsku okolo 20-tisíc Slovákov. Slovenské etnikum v Rumunsku možno rozdelit do dvoch vel'kých, teritoriálne navzájom oddelených skupín. Prvú z nich nachádzame v nížinatej, severnej časti rumunského Banátu (v Aradskej župe) v okolí mesta Nadlak. Ide o ekonomicky a kultúrne pomerne vyspelú populáciu - v Nadlaku pôsobí aj slovenská stredná škola a v slovenčine vychádzajú knižné publikácie. V ich prípade ide o tzv. druhotnú kolonizáciu, ktorá zo začiatku 19. storočia prišla na toto územie pôvodne z oblasti Békešskej Čaby. Druhá, kultúrne menej vyspelá zložka slovenskej populácie, sídli na severozápade krajiny v obciach rumunského Rudohoria, ležiaceho východne od mesta Vel'ký Varadín na hraniciach žúp Bihor a Salaš. Ide o potomkov kolonistov, ktorí prišli na toto neobývané miesto v troch vlnách medzi rokmi 1790-1838. Velká čast 
týchto Slovákov sa zúčastnila aj na emigračnej vlne do Československa v rokoch po druhej svetovej vojne. Boli usídlovaní najmä v pohraničí Čiech a Moravy (napr. Jeseníky alebo Tachovsko), kde sú dodnes vel'mi osobitnou kultúrnou skupinou obyvatel'stva.

V súčasnom Srbsku (vo Vojvodine) žijú najmä Slováci - emigranti z 18. a 19. storočia, tvoriaci tretiu najpočetnejšiu národnost'. Sú absolútnou väčšinou v obci Báčsky Petrovec a najvýznamnejšou národnostou v obci Kovačica. Celkovo žije v Srbsku okolo 56-tisíc Slovákov: sú potomkami prevažne evanjelických vystahovalcov z 18. storočia, ktorí sa usadili na úrodnom území, riedko obývanom po spustošení Turkami. Dodnes si značne zachovávajú jazyk i folklórne zvyky svojich predkov; vytvárajú kultúrne vyspelé hodnoty.

Významnou vetvou tohto komplexného procesu je vlastne literárna tvorba Slovákov v zahraničí. Ona je striedmym zrkadlom života či mysle ludí, ktorí často len snívajú o svojej pravlasti. V tých končinách má, prirodzene, po slovensky písané slovo väčšiu váhu a gradované poslanie ako na Slovensku: je akousi buditelkou, ale aj strážnym majákom slovenskosti. A práve ono je predmetom záujmu novej publikácie Patrika Šenkára s názvom Slovenská dolnozemská literatúra (v teórii a praxi).

Patrik Šenkár, odborný asistent Katedry slovenského jazyka a literatúry Pedagogickej fakulty Univerzity J. Selyeho v Komárne, sa vo svojej literárnovednej činnosti ako jeden z mála odborníkov zo slovenskej akademickej sféry zameriava najmä na literárnu tvorbu dolnozemských Slovákov. Skúma ich tvorivú beletristickú činnost'; systematicky analyzuje, porovnáva a originálne interpretuje ich diela využitím viacerých kontextov. Tým vlastne taktiež zviditelnuuje a približuje fenomén tejto literatúry (aj) na Slovensku.

Dovolíme si povedat, že okno do sveta dolnozemských Slovákov otvorili Patrikovi Šenkárovi najmä spisovatel' a literárny vedec Peter Andruška a Mária Katarína Hrklová, bývalá zástupkyňa viacerých riaditelov Domu zahraničných Slovákov v Bratislave. Boli to práve oni, ktorí svojho času upozornili, podnietili a usmernili budúceho autora, aby sa zameral na vyplnenie bielych miest dolnozemskej literatúry.
Šenkárova aktívna účast̉ na medzinárodných konferenciách v Nadlaku (od roku 2009) na počest’ básnika Ondreja Štefanka prispela k jeho aktívnemu poznaniu špecifickosti tejto literatúry. Svojej úlohy sa zhostil so zápalom a zodpovedne. Pochopil, a dokazuje to aj v publikácii, že do slovenskej literatúry patrí aj literárna tvorba Slovákov žijúcich v zahraničí. Svojou špecifickostou je ona (už spomínaným) obohatením slovenskej literatúry na území Slovenska, ale aj na Dolnej zemi. Slovenská dolnozemská literatúra pritom spája krajanov i Slovákov doma, ako to neraz rôznorodí autori dokázali vo svojich prezentáciách v minulosti aj v Dome zahraničných Slovákov.

Šenkárova publikácia - ako vysokoškolská učebnica - podáva v troch hlavných kapitolách základné literárno-historické údaje, d’alej konkrétne ukážky z tvorby: najprv poéziu a za ňou prozaické texty a napokon bibliografiu s obrazovou prílohou. Túto štruktúru autor uplatnil rovnako pri prezentovaní slovenskej literatúry v Mad’arsku, Rumunsku a Srbsku. V závere knihy je výberová odporúčaná literatúra a publikáciu uzatvárajú vydavatel'ské posudky Petra Andrušku, Rudolfa Chmela a Kataríny Maruzsovej Šebovej.

Autorom skúmaná problematika (so zretelom učit kultúrnosti a rozumiet kultúre) patrí preto k aktuálnym a prínosným otázkam: predstavuje obraz prozaickej, lyrickej a dramatickej tvorby v pozadí jednotlivých diel. Je výsledkom rozsiahlej práce, teda môže tým zaplnit (už spomínanú) medzeru v slovenskom literárnom korpuse. Výber témy celkovo nesie v sebe akúsi pečat vstupu v podstate na neznámu pôdu, ved' literatúra zahraničných Slovákov bola dlhodobo vnímaná len ako akási okrajová záležitost́. Bádatelia, medzi ktorých patrí aj P. Šenkár, však dokázali, že slovenská dolnozemská literatúra predstavuje historický fenomén, ktorý je prirodzeným prejavom národnej identity. Jeho kniha - v chápaní Rudolfa Chmela - predstavuje tento atribút „... $v$ tematickej, žánrovej, poetologickej rôznorodosti aj axiologickej stratifikácii, z ktorej sa čitatel' má možnost' zoznámit's jej najcharakteristickejšimi predstavitel'mi“.

Publikácia je vlastnou cestou zorientovania sa v základných súradniciach slovenskej literatúry z Dolnej zeme. Šenkár nielen študoval, ale so 
svojimi osobnými kontaktmi s dolnozemským kultúrnym prostredím aj dokladoval zretelný, autorský prístup $\mathrm{k}$ jednotlivým textom i metatextom. Ved' aj on publikuje doma i v zahraničí (Česko, Mad’arsko, Rumunsko...) na danú tému v zborníkoch, časopisoch, novinách a zúčastňuje sa knižných veltrhov či konferencií. Všade tam deklaruje dolnozemskú literárnu tvorbu - teda prispieva k jej propagácii. A to je pre všetky zúčastnené strany vel'mi dôležité a osožné!

Spomínaná kniha je preto úspešnou sumarizáciou intenzívnej (fyzickej i psychickej) cesty autora za slovenskou literatúrou zo zahraničia. Táto tvorba je vlastne akýmsi absolútnym volaním po väčšej pozornosti z aspektu domácej (teda na Slovensku vznikajúcej) literárnej proveniencie. Šenkár sa vo svojej práci - ako sa vyjadril dôkladný znalec tejto problematiky Peter Andruška - podujal „... na nel'ahkú a svojím spôsobom aj riskantnú robotu predstavit dolnozemských slovenských autorov ukážkami z ich diela, čim významne prispel $k$ dôvernejšiemu poznaniu dolnozemskej slovenskej literatúry“. Týmto spôsobom teda Šenkár prináša nový, objektívno-subjektívny pohlad na život, kultúru a literatúru dolnozemských Slovákov. Poukazuje na dôležitost’ a špecifickost’ slovenskosti na tomto území či na potrebu chápania slovenskej literatúry ako jednotného celku. Vychádza pritom zo špecifickosti národnostného bytia dolnozemského človeka. Prízvukuje potrebu kontinuity, ktorú deklaruje tvorivou líniou týchto autorov nielen dávnejšej minulosti, ale aj absolútnej prítomnosti.

Šenkár hladá korene a špecifiká existencie slovenskej národnosti. Ich konkretizáciou sú jednotlivé biografické a bibliografické portréty osobností literárneho vývinu tej-ktorej národnosti. Charakterizuje ich rôznorodú literárnu tvorbu v časovom slede, t. j. vnútorný význam či zmysel ich tvorivej práce. Využíva dostupnú odbornú literatúru, ale spolieha sa aj na vlastný objektívno-subjektívny vkus. Tým dostáva táto „komentovaná antológia“ komplexnejší ráz a prítažlivejšiu podobu pre záujemcov.

Súhlasíme s myšlienkou Kataríny Maruzsovej Šebovej, ktorá hovorí, že autor kladne identifi- kuje formovanie obrazu o tejto literatúre ako o integrálnej súčasti slovenskej národnej literatúry. Jeho publikácia $\mathrm{v}$ širšom kontexte má šancu vyplnit biele miesta literárneho priestoru, a tým postupne vytvárat v mladej generácii slovakistov vedomie o jednotnom národnom literárnom korpuse.

Ešte raz chceme zdôraznit základný atribút knihy, v ktorej sa autor snažil prepojit teoretickú bázu s praktickými ukážkami v kontexte dolnozemského literárneho fenoménu. Jadro knihy teda tvorí antologická čast', do ktorej autor vyberal texty z dostupných materiálov na základe vlastného uváženia. V poslednej kapitole ponúka Šenkár čitatelom bohatý súbor výberovej odporúčanej literatúry, ktorú reprezentujú odborné i vedecké práce, ako aj monografie rôznych autorov. Pri prezentovaní selektovaného materiálu sa prejavuje aj ako skúsený didaktik, ved' o. i. štruktúra jeho práce je celkovo logická a prehladná. Vo výbere textov do antologickej časti uplatnil princíp kvality, ako aj osobný vkus (klasické i postmoderné texty) - pričom tieto dva aspekty sú v úplnom súlade.

Poradie autorov v úvodných kapitolách, ale aj ich zaradenie, je subjektívnym výberom autora. Z jazykového hladiska bol zásah do konkrétnych literárnych textov iba tam a vtedy, ked' išlo o dodržiavanie Pravidiel slovenského pravopisu, pričom sa tolerovalo aj isté vybočenie $\mathrm{z}$ jazykových predpisov. Základným pilierom pri tvorbe tejto učebnice bola Andruškova publikácia Literárna tvorba Slovákov z Dolnej zeme (1994, 2013), ale aj Slovnik slovenských spisovatelov Dolnej zeme (1994) kolektívu autorov Balážová - Bartalská Fazekašová - Hronec - Štefanko.

Na záver možno konštatovat', že odborná a metodická úroveň publikácie (ktorá vyšla v rámci projektu, ktorý je spolufinancovaný zo zdrojov Európskej únie a nesie názov Moderné vzdelávanie pre vedomostnú spoločnost), ako aj výber a kvalita textového materiálu je dobrá. Publikácia dozaista poslúži pri štúdiu slovenskej literatúry pre zainteresovaných. A tým splní svoj deklarovaný ciel. 